\title{
The Livonian Rhymed Chronicle as a Transitional Text: Formulaic Language in Middle High German Verse History
}

La Crónica rimada de Livonia como texto transicional: lenguaje formular en la historia versificada en alto alemán medio

AlAN V. MURRAY

University of Leeds

4.07 Parkinson Building

Leeds LS2 9JT, Great Britain

a.v.murray@leeds.ac.uk

Orcid ID 0000-0003-1641-0891

\begin{abstract}
This essay investigates the transitional character of the Livonian Rhymed Chronicle (German: Livländische Reimchronik), a Middle High German verse history composed around 1290, which describes the conquest of the eastern Baltic lands by German crusaders and military-religious orders during the thirteenth century. Although it was first composed as a written text, the chronicle shows numerous features characteristic of oral-formulaic poetry: stock epithets, fixed nominal pairs, repeated discourse markers, and syntactic formulas used to introduce persons and places. The analysis is followed by an investigation of the probable audience and performance situation of the work. It is argued that the highly formulaic features of the work were designed to aid comprehension by listeners who were not necessarily familiar with the language variety in which the chronicle was composed.
\end{abstract}

Keywords: Historical Linguistics. Middle High German Poetry. Formulaic Language. Discourse Markers.
Resumen: Este trabajo investiga el carácter transicional de la Crónica rimada de Livonia (en alemán: Livländische Reimchronik), una historia versificada en alto alemán medio compuesta hacia 1290, que relata la conquista de las tierras bálticas orientales por cruzados y órdenes religiosas militares alemanes durante el siglo XIII. Aunque se compuso originalmente como texto escrito, la crónica muestra numerosos rasgos de la poesía oral formular: epítetos estereotipados, parejas nominales fijas, marcadores discursivos repetidos, y fórmulas sintácticas para presentar personas y lugares. Al análisis sigue una investigación de la probable audiencia y contexto de ejecución de la obra. Se argumenta que los rasgos marcadamente formulares de la obra estaban dirigidos a favorecer la comprensión de oyentes que podían no estar familiarizados con la variedad lingüística en que se compuso la crónica.

Palabras clave: Lingüística histórica. Poesía en alto alemán medio. Lenguaje formular. Marcadores discursivos. 


\section{INTRODUCTION}

7 he period between the years 1170 and 1220 saw a fundamental shift in the character of the transmission of poetry composed in Middle High German (MHG), the term applied to the range of related dialects spoken in southern and central Germany at the time. Many of the epic poems thought to have been in existence before this time exhibit many features which suggest that they were composed and transmitted orally long before they were ever written down. It was only the act of writing that fixed the forms which had once been far more fluid within the accepted parameters imposed by the conventions of formulaic poetic language. However, by 1220 most new works were being recorded and transmitted in writing, even if the expense of materials and the widespread illiteracy of audiences meant they were still mostly performed by being read aloud to audiences (Curschmann 1967: 37; Curschmann 1979; Hartmann 2015: 15-16). ${ }^{1}$

The older form of orally transmitted poetry is exemplified by the anonymous Nibelungenlied, a heroic epic which tells of the murder of the hero Sifrit at the hands of three kings of the Burgundians and their vassal Hagen, and the vengeance taken against the murderers by Kriemhilt, sister of the Burgundian kings and widow of Sifrit. The earliest surviving form of the poem was written down around the year 1200, but Germanists have long disagreed whether this version was composed orally or in writing. Nevertheless, there is broad agreement that it was the end product of an oral tradition, in that it drew on poetic material which had originally been composed orally and which had been in oral circulation for many years previously. It is also likely that it was performed orally by poets who relied on their memory rather than a written text. The poem comprises 39 sections described as âventiuren (literally 'adventures'). Depending on their length, one or more of these units could be comfortably performed and listened to in the course of an evening. By contrast, the sheer length of the poem makes it highly unlikely that anyone ever heard it recited from beginning to end, and partial listening was the usual form of its reception. ${ }^{2}$

1. References to the works discussed in this essay are given to strophes or lines in the standard editions listed in the bibliography. English translations of passages from the Nibelungenlied and the Livonian Rhymed Chronicle are by the author; a fairly literal approach to translation has been taken in order to bring out the linguistic issues under discussion. The translation of the single quotation from Wolfram's Parzival is taken from Edwards.

2. The complete literature on oral and formulaic aspects of the Nibelungenlied is too extensive to be cited here. Important contributions include: Capek; Bäuml and Ward; Haymes 1975, 1976 and 2004; Curschmann 1979; Bäuml; Heinzle. 


\section{ORAL AND WRITTEN COMPOSITION}

One of the key features of orally transmitted poetry is the formulaic nature of much of its language. The poet was generally constrained by his memory on the one hand, and the need to keep the narrative going on the other. To this end poets in many pre-literate societies have made extensive use of formulas to serve as building blocks of narrative. One of the features of the Nibelungenlied which derive from its oral antecedents is formulaic epithets applied to characters. Thus three of the members of the Burgundian court at Worms who are introduced in Âventiure 1 are each described as ein $\hat{u} z$ erwelter degen ('an excellent warrior'):

und Gîselher der junge, ein ûz erwelter degen. (NL 4)

'Gîselher the Young, an excellent warrior'

Rûmolt der kuchenmeister, ein ûz erwelter degen. (NL 10)

'Rûmolt the master of the kitchen, an excellent warrior'

Sindolt der was scenke, ein ûz erwelter degen. (NL 11)

'Sindolt was the butler, an excellent warrior'

This phrase offers no real characterisation. However, it has a metrical function of filling a half-line, so that - as in these examples - it can be simply combined with a preceding noun phrase (NP) of a suitable length which names the character concerned, in order to create a complete line of poetry.

There is also a high degree of formulaicity in the phrasing used to introduce instances of direct speech (so-called inquit-formulas), which combine names with descriptions, often on the pattern dô sprach ('then said') + NP incorporating an attribute and name. This combination most frequently fills a half-line at the beginning of a strophe, e.g.

Dô sprach der künec Gunther... (NL 350, 427, 530, 611, 621, 734, 855, $857,874,1129,1131,1190,1450,1484,1994,2264)$

'Then King Gunther said...'.

The inquit-formula can also form a complete line by extension of the noun phrase, as in the case of Gernôt, the second of the three royal Burgundian brothers:

Dô sprach von Burgonden der herre Gernôt. (NL 288, 1569, 1577)

Dô sprach von Burgonden der küene Gernôt. (NL 110)

Dô sprach von Burgonden der recke Gernôt. (NL 1197) 
Gernôt is described with three different attributes: the nouns herre ('lord') and recke ('warrior'), and the adjective küene ('bold'). Yet these descriptions are essentially minor variations of a single formula whose essential characteristic is that it fills a complete line.

Also common are periphrastic constructions, which allow the poet to avoid repeating names where their position might make rhyming difficult. Thus the formula NP-Gen + kint (literally 'child', i.e. son or daughter) can be employed to describe Gernôt as daz Uoten kint 'the son of Uote' (NL 126), while Sifrit is named as daz Siglinde kint 'the son of Siglinde' (NL 47). Similarly the phrase min lipp (literally 'my body/person') can be used as a synonym for the first person pronoun. These forms are often used in preference to actual names or personal pronouns, especially at the end of a line, in order to facilitate the use of an appropriate rhyme in the preceding or following line. Thus the words kint and lip in such constructions are frequently rhymed with sint ('[they] are') or wîp ('woman'). In these and other examples it is the demands of metre and rhyme that largely determine the character and occurrences of formulas.

The development towards composition in writing was spurred on by different factors. One was increasing patronage by both secular and ecclesiastical princes, and the associated provision of more congenial circumstances and materials (such as parchment) for poets (Bumke 1979; Bihrer). More important, however, was the taste for poems involving more sophisticated characterisation and plots, especially those dealing with Arthurian themes which were either adapted from or inspired by French originals. A parallel development was a greater prominence achieved by authors themselves. The poets of the Nibelungenlied and other heroic epics were transmitting long-established tales whose basic plots were probably well known to their audiences, and they remained anonymous. By contrast, poets of Arthurian romance such as Hartmann von Aue and Wolfram von Eschenbach were producing novel adventures and wished to highlight their originality as authors; they not only name themselves within their works, but often exploit their own identities (and presumably, their audiences' knowledge of them) in playful fashion to make moral or humorous points (Jackson 194-209; Ridder; Hahn 110-24).

Some complexities of this new literary fashion can be illustrated by the romance Parzival by Wolfram von Eschenbach, composed around 1215. The core story tells of the eponymous hero's quest to find the Grail, an adaptation of Perceval (Le Conte del Graal) by the French poet Chrétien de Troyes. However, 
Wolfram interweaves this action with a parallel story of his own invention, involving another knight, Gawan, and also provides an opening narrative framework describing the life of Parzival's father Gahmuret (Hartmann 42-72). Wolfram deploys a range of characters far in excess of those of the Nibelungenlied and related works. He uses a highly innovative syntax and vocabulary (Hartmann 57-67; Brüggen and Lindemann). He also makes use of his own capability for invention rather than drawing on literary tradition. This feature is especially noticeable in several long lists of precious stones or warriors in an army, most of whose names derive from Wolfram's own imagination. For example, in Book XV there is a passage listing the kings and princes in the service of Parzival's half-brother Feirefiz, who has grown up in heathendom:

Der künec Papirîs of Trogodjente, und der grâve Behantîns von Kalomidente, der herzoge Farjelastis von Affricke, und der künec Liddamus von Agrippe, der künec Tridanz of Tinodonte und der künec Amaspartins von Schipelpjonte, herzoge Lippidins von Agremuntîn, und der künec Milôn von Nomadjentesîn, von Assigarzîonte der grâve Gabarîns, und von Rivigitas der künec Translapîns, von Hiberborticôn der grâve Filones und von Centriûn der künec Killicrates, der grâve Lysander von Ipopotiticon, und der herzoge Tiridê von Elixodjôn [...]. (Parzival 770,1-14)
King Papiris of Trogodjente, and Count Behantins of Kalomidente, Duke Farjelastis of Affricke, and King Liddamus of Agrippe, King Tridanz of Tinodonte and King Amaspartins of Schipelpjonte, Duke Lippidins of Agremuntin, and King Milon of Nomadjentesin, of Assigarzionte Count Gabarins, and of Rivigitas King Translapins, of Hiberborticon Count Filones and of Centriun King Killicrates, Count Lysander of Ipopotiticon, and Duke Tiride of Elixodjon [...]. (Edwards 322)

This short illustration gives fourteen names, but the single sentence from which it is taken goes on to list a total of thirty names. Such lists in the works of Wolfram, Hartmann von Aue and other Arthurian poets seem designed to impress an audience with the author's fantasy and creativity. ${ }^{3}$ However, they would scarcely have been recognisable to an audience hearing such a passage for the first or even a subsequent time. It is difficult to believe that any per-

3. For other examples, see Parzival 772,1-23 and 791,1-30, and Erec 1630-1693. By way of comparison one may note that, depending on the variant text, the Nibelungenlied does not give more than around 70 personal names in total. 
former was capable of memorising such densely constructed lists of exotic, polysyllabic and unfamiliar names and reproducing them orally from memory only. It is no coincidence that each of the lists given by Wolfram takes up thirty lines or slightly less, and the use of such units is a characteristic of the entire work. It has been convincingly argued that this was the length of text that could comfortably be accommodated on a single wax tablet, before it was transferred to a manuscript in a fair copy (Hartmann 15-16). These lists and the form in which they appear are thus strong evidence that the composition process of Wolfram's work involved his poetry being written down, even though it was primarily read aloud in performance.

Thus while much of the traditional, orally transmitted poetry continued to be recited from memory, by the mid-thirteenth century most new works were composed on wax tablets and parchment, and recited by a performer who had access to at least a partial written version of the work. Nevertheless, this was not a purely one-way process. The subject of this essay is a work of verse history which was certainly composed in a written form, but nevertheless includes numerous formulaic features characteristic of oral poetry.

\section{Verse History: The Livonian Rhymed Chronicle}

While vernacular history writing in the Francophone countries gradually shifted from verse to prose in the course of the thirteenth and fourteenth centuries, in the German- and Dutch-speaking lands and Scandinavia poetry remained an important vehicle for history writing well into the fourteenth century (Mitchell). Thus much Middle High German historiography shares many generic features of imaginative poetry. One example of a vernacular verse history in that period is the Livonian Rhymed Chronicle (known in modern German as the Livländische Reimcbronik), composed between the years 1290 and 1300 by an anonymous author who is generally thought to have been a member of the Teutonic Order. ${ }^{4}$ The chronicle has never been considered to have any great literary merit; rather, its importance derives from the fact that

4. The Rhymed Cbronicle was far less widely transmitted than the other works discussed here. Only two complete manuscripts are known: $\mathrm{R}=$ Riga, Bibliothek der Livländischen Ritterschaft (now lost) and $\mathrm{H}=$ Heidelberg, Universitätsbibliothek, cpg. 288. Line references given in this essay relate to the MHG text established by Meyer (1876), which is reproduced in the published translations into Latvian (Bisenieks), Estonian (Eelmäe) and Italian (Bugiani). The only commercially available English translation (Smith and Urban) does not include the MHG text. 
it is one of a small number of narrative sources dealing with the conquest and Christianisation of Livonia (roughly corresponding to modern Latvia and Estonia) by German crusaders and warrior monks during the thirteenth century. By the time of the chronicle's composition Livonia was constituted as a conglomeration of territories in which sovereignty was divided among the Teutonic Order, a number of bishoprics, and the kingdom of Denmark. Germans provided the upper strata of nobles, clerics, monks and burgesses among the majority native populations whose tongues belonged to the Finnic and Baltic language groups (Murray; Kala). Most of the chronicle's content deals with the wars fought by the Teutonic Order and its predecessor, the Order of the Sword Brethren, against hostile indigenous peoples: the Livs, Letts and Estonians were mostly conquered and Christianised by about 1230, while wars continued for the remainder of the thirteenth century against the pagan Curonians, Semgallians, and Lithuanians, who inhabited the areas to the south and east of Livonia, and the Russians of the principalities of Pskov, Izborsk and Novgorod, who although Orthodox Christians, were regarded by the Teutonic Order as schismatics and thus enemies of the Catholic faith (Meyer; Angermann; Tarvel; Kugler; Murray).

The chronicle's language is an East Central variety of Middle High German. The text consists of 12017 lines in rhyming couplets, with each line containing three or four stresses. The scholarly consensus is that it was performed by being read aloud to audiences whose members were illiterate, although it is a matter of debate who constituted these audiences, a point to which we shall return. Certainly the phrasing of the poem includes instances of direct address, such as als ir habt vernomen ('as you have heard'), which suggest oral performance (LRC 4606, 8798, 8806, 9158, 9178, 9240, 9596). However, unlike the Nibelungenlied, the Rhymed Chronicle has no formal internal divisions which might correspond to performance units, although the chronicle is far too lengthy to be heard at a single sitting.

\section{FORMULAIC VOCABULARY}

One major difference between the older, orally transmitted works and the newer romances is their choice of vocabulary. The Nibelungenlied, as well as other older heroic works such as Kudrun, the late twelfth-century epic Rolandslied, and the verse history known as the Kaiserchronik, tend to describe warriors by older (and essentially interchangeable) words for warrior: helt, degen, recke and wigant. They make relatively little use of the newer and more 
fashionable term ritter ('knight'), which, however, predominates in Arthurian romances such as Parzival, Erec by Hartmann von Aue and the anonymous Wigalois. Although it was composed at a later date than any of these works, the Rhymed Chronicle shows a preponderance of the older vocabulary, with the two heroic terms helt and degen together outweighing ritter by a proportion of three to one (Bumke 1982 17-21; Murray 246-47). ${ }^{5}$

Descriptions of combat make use of stock, repeated ideas and vocabulary, especially of armour and weaponry:

man sach helme und schilde

glîzen ûf dem gevilde,

die brunjen blenken sam ein glas. (LRC 3281-83)

sie bereiten sich dô

ûf die vart mit vlìzen.

man sach dâ helme glîzen,

ir brunjen wâren silbervar. (LRC 4750-53)

die Semegallen ouch aldar

quâmen ouch mit vlîzen.

dô sach man helme glîzen,

brunjen blenken sam ein glas. (LRC 8338-42)
Helms and shields were seen

shining in the field,

the hauberks glistening like glass

Then they prepared themselves

for the campaign with diligence.

Helms were seen shining there,

their hauberks were like silver

The Semgallians also

came with enthusiasm.

Helms were seen shining then, and hauberks glistening like glass.

These descriptions could be expected to appeal to men who were warriors themselves. ${ }^{6}$

Another feature linking the Rhymed Chronicle with heroic poetry is the use of formulaic constructions filling a complete line. One such is the fixed expression roub und brant ('plundering and burning'), which is used of both Christian armies and their pagan and schismatic opponents. This phrase tends to figure in a collocation with the verb stiften ('undertake, carry out'), and the two words are invariably given in the same order, which facilitates rhymes with the common word lant ('land') and the frequently used proper name Nieflant ('Livonia'):?

sie stiften roub und brand

mit mancher schar wunneclîch. (LRC 1902-03) they carried out plundering and burning with many fine forces

5. The formula ein vromer belt ('a pious warrior') is typically used to describe knight brethren of the Teutonic Order (LRC 626, 2299, 5246, 5699, 8523, 8713, 10763, 10966).

6. Similar examples occur at lines 1085-86, 2374-75, 5018-19, 10410-11.

7. Similar examples occur at lines 2698, 6004, 6498, 6902. 

$\mathrm{Zu}$ Darbete wart vernomen
At Dorpat it became known
kunic Alexander wêre komen that King Alexander [Nevskii] had come mit her in der brûder lant with his army into the land of the brethren und stifte roub und brant. (LRC 2225-28) [Teutonic Knights] and was plundering and burning
si riten wider in sîn lant they rode back into his land und stiften roub unde brant. (LRC 2755-56)
and carried out plundering and burning.

To meet the requirements of metre, the poet makes extensive use of pairs of words which fill a complete line of poetry:
(die) burger(e) und (die) pilgerîn.
(the) burgesses and (the) crusaders
(LRC 4417, 10415, 10577)
beide arme und rîche.
both poor and rich

(LRC 1046, 1345, 1646, 1880, 1940, 7029)

The most common formula on this pattern relates to the converted Livish and Lettish peoples, who figure as military allies or auxiliaries of the Christians:
die Letten und die Lîven
The Letts and Livs
zû hûs nicht wolden blîven. (LRC 1893-94)
did not want to remain at home
die Letten und Liven
The Letts and Livs
die wolden stête blîben
wanted to remain firm
bie deme cristemtûme. (LRC 1079-81)
in the Christian faith
Der meister und die brûdere sîn
The master and his brethren
und vil manich pilgerîn, and many a crusader,
Letten und Liven
die enwolden nicht belîven. (LRC 1377-78)
Letts and Livs
did not want to remain behind.

This alliterative pair is almost invariably lexicalised in this standard order, and rhymed with the verb bliven / blîben 'remain'. This basic formula can also be used after prepositions: an Letten und an Lîven (907); nâch Letten und nâch Lîven (1741); mit Letten und mit Lîven (898), as well as in terms of address in direct speech: ir Letten und ir Liven (1521). ${ }^{8}$ Each of these phrases thus fills a

8. For similar examples, see lines 526, 1117, 1148, 1185, 1252, 1392. 
complete line of poetry. The recurrence of such pairs shows how the poet repeatedly resorted to existing formulas in order to construct substantive units, whose precise order was determined by the need to find easy rhymes.

\section{Formulaic SYNTAX}

A common feature of the Livonian Rhymed Chronicle is a syntactical construction which is used in connection with names of places or people. This is structured as a sentence comprising NP + auxiliary verb + NP/pronoun + PP genant ('named, called'), as can be seen in the following examples dealing with the castle of Heiligenberg:

der Heiligeberc wart sie genant, ir name wart sint wol bekant. (LRC 9939-40)

der Heiligeberc was er genant

und lac in der viende lant. (LRC 10945-46)

dô man gote getrûwete

und ein hûs gebûwete

zû Semegallen in daz lant, der Heiligenberc wart ez genant. (LRC 11615-18)
It was named Heiligenberg, and its name has become well known since then.

It was named Heiligenberg, and lay in enemy territory. then they put their trust in God and built a house in the land of the Semgallians; it was named Heiligenberg.

These examples are an indication of the episodic character of the performance of the work. Even in a case where a place has already been described, it was necessary to re-introduce it if this were the first instance occurring in a portion of the chronicle that was being read aloud on a given occasion. Yet this consideration only partially explains the use of the formula. It is also used with the names of people or places which occur so frequently that they really need no introduction or explanation whatsoever, especially when they figure at a relatively late point in the narrative. Thus, after a long description of how the Russians have invaded the area around Dorpat (mod. Tartu, Estonia), the poet tells how the master of Livonia assembles diverse forces to carry out a retaliatory attack.

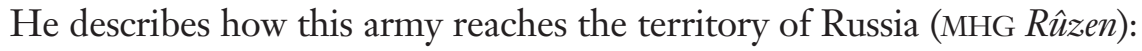

dô sie quâmen vor daz lant, daz dâ Rûzen ist genant. (LRC 7699-7700)
Then they arrived at the land that is called Russia.

Anyone listening to a narrative about the Baltic Crusades in the fourteenth century was of course aware of Russia and its people. As the chronicle has de- 
scribed Russian attacks on Livonia shortly before this passage, the name R $\hat{u} z e n$ requires no explanation. Rather, in this instance the introductory formula with the past participle genant seems to highlight the importance of Russia as a subject. This function can also be seen in the way that it is used in connection with persons, most specifically with those who held the position of master of Livonia, the senior office of the Teutonic Order in the country. Thus one passage describes a meeting between Poppo, grand master of the Teutonic Order, and Anno von Sangerhausen, master of Livonia, who is chosen as his successor:

dâ sie den meister vunden

meister Poppen von Ôsternâ.

er entpfienc sie liplîchen sâ.

von Nieflande was ouch komen

ein geistlîch man vil wol vernomen,

brûder Anne was er genant.

er was meister zû Nieflant. (LRC 4332-38)
They found the master there, Master Poppo von Osternau.

He received them kindly.

There also arrived from Livonia a man who was well known to be religious, who was named Brother Anno.

He was master of Livonia.

A similar construction occurs at the point that Brother Walter von Nordeck is sent by the grand master (who was resident in Prussia) to take up office as the new master of Livonia:

ein vromer helt der wart gesant

zû meister hin zû Nieflant.

er hatte sinneclîchen rât, daz sult ir hôren an der tât, die er tete bie sîner zît.

sîn name was grôz und wît uber all die lant.

brûder Walter was er genant

von Nortecken geborn. (LRC 7995-8003) a pious warrior was sent as master to Livonia.

He was a man of sensible counsel, as you shall hear from the deeds that he accomplished in his time. His name was known far and wide through all the lands.

He was named Brother Walter, born in Nordeck.

Another case occurs when Master Konrad von Feuchtwangen asks to be relieved of his office, and is replaced by Willekin von Nindorf:

er hatte gerâten, daz ist wâr, in deme lande drittehalb jâr.

Alsô wart er des amtes lôs. einen brûder man dô kôs zû meister uber Nieflant:

brûder Willekîn was er genant. (LRC 9628-9734)
In truth he had served in the land for three and a half years. And so he was relieved of the office. Then a knight brother was chosen as master of Livonia:

he was named Brother Willekin. 
The only evident structuring principle of the narrative is the periods of office of the masters of Livonia, so one might well expect an introductory formula to be used when these names first appear. However, the naming phrase using the past participle genant is used far more frequently than simply to introduce masters. This formula fills a complete line, but it also functions as a discourse marker which is used to fix attention on a particular person or place which will figure as the locus of the following action. ${ }^{9}$

By far the most common example of formulaic syntax is a construction which serves to comment on a foregoing narrative. It is formed with the adjective vrô, meaning 'glad', 'happy', 'pleased', or 'joyful'. Beyond its simple use as an attribute or predicate, it occurs in more specific formulas which serve the requirements of metre by filling a complete line. These can be divided into two types based on different syntactic forms.

In the first type the construction is formed with substantives, occurring 58 times in the entire chronicle. These mostly relate to discourse, such as rede (speech), mêre (news), rât (advice, counsel), or to events which often figure as subjects of speech acts, e.g. reise (campaign) or vrîde (peace). Thus one passage relates how a messenger brings news that an army of Lithuanians is approaching Christian territory. The text gives a positive judgement on the fact that a timely warning has been conveyed to the master of Livonia:

dô daz dem meistere wart bekant, der warnunge was er vrô. (LRC 2099-2100)
When this was made known to the master, he was glad of the warning.

The same construction can also be used with the negative adjective unvrô:

Die von Plezcowe dô

wâren diser mêre unvrô. (LRC 2099-2100)
The people of Pskov then were dismayed by this news.

The formulaic nature of the construction can be seen in the fact that it appears repeatedly with minimal variation. Thus, shortly after the previous instance the text goes on to report how the knight brethren of the Teutonic Order invade the territory of the city of Pskov in north-western Russia. This shows an instance of humour, playing on the dual meanings of the MHG word gast (pl. geste), which can mean both 'guest' and 'stranger, outsider'; thus the Brethren are portrayed as unwelcome guests of the Russians:

9. For additional examples, see LRC lines 139, 2133, 2208, 2734, 3832, 4337, 4407, 4467, 4732, 4831, 6992, 8879, 11881. 
Die von Plezcowe dô

wâren der geste unvrô.

die brûdere slûgen ir gezelt

vor Plezcowe ûf ein schône velt. (LRC 2137-40)
The people of Pskov then

were dismayed by the guests.

The brethren put up their tents

on a beautiful meadow before Pskov.

The second type of the construction links syntactic units by using the unspecific genitive demonstrative pronoun des to refer to a preceding or following clause. For example, a short report tells how the Teutonic Knights were able to locate and approach an army of Lithuanian pagans without being seen themselves:

sie quâmen in vil kurzer stunt

den Lettowen alsô nâhen, daz sie ir her besâhen.

des wurden sie von herzen vrô. (LRC 11889-92)
In a short time they came

so close to the Lithuanians

that they could observe their army;

they were heartily pleased by this.

This more extended form frequently appears in a variety of constructions in order to sum up the outcome of a passage described in a foregoing section of narrative. Thus a section telling of the election of Dietrich von Grüningen as master of Livonia (LRC 2332-62) concludes by stating how he intends to launch a campaign against Curonia:

er wolde heren Kûrlant.

den brûderen tet er daz bekant.

des wâren sie von hertzen vrô.

mit aller macht sie hûlfen dô,

daz ez wurde vollenbrâcht,

als der meister hatte gedâcht. (LRC 2357-62)
He wished to harry Curonia, and made this known to the brethren, who were all overjoyed at this. They did their utmost to help bring about what the master had planned.

This more complicated construction occurs 71 times in the chronicle (59 in a positive sense, 12 in a negative). Such repetition, which one imagines would have been avoided by a better stylist such as Wolfram von Eschenbach, does not seem to matter to the poet; in fact we often find similar constructions occurring in relatively close proximity. Thus the chronicle relates how Albrecht, count of Orlamünde, the leader of an army of German crusaders, speaks to the master of the Order of the Sword Brethren to outline a forthcoming campaign against the pagans:

grêve Albrecht der sprach dô: $\quad$ Count Albrecht then said: 
‘ich bin des von herzen vrô,

daz ich die heiden sûchen sol.

ich getrûwe dem gûten gote sô wol,

daz wir uns an in rechen sô,

daz sie des nimmer werden vrô'.

(LRC 1369-74)
'I am heartily pleased that I should seek out the heathens. I trust the good Lord so much that we should revenge ourselves on them, so that they will never be happy as a result'.

Similarly, another scene relates how Master Andreas von Stirlant makes a speech to his officers, announcing his intention to lead an expedition against pagan Lithuania. The response of the officers is given in direct speech, and the text goes on to detail the preparations for the forthcoming campaign, making use of the two different constructions with the adjective vrô:

die kummentûre sprâchen dô:

'meister, wir sîn der rede vrô;

ûwer wille sol dar an

geschehen wol'. zû hant von dan

ritten sie vil drâte.

nâch des meisters râte

geboten sie die herevart;

des enwart niemant gespart.

daz volc zû widerstrîte

vreute sich der zite,

daz iz solde reise varn.

die brûdere mit vil stoltzer schar

quâmen dem meister dô.

des was er von hertzen vrô. (LRC 3265-78)
The commanders all said then,

'Master, this speech pleases us;

in this matter your will

shall be done'. Immediately

they rode away and ordered the expedition

to be made according

to the master's advice;

no one was excused duty.

The people were all pleased

that they were to go on campaign.

Then the brethren came

with many a proud troop

to the master.

He was heartily pleased by this.

The many descriptions of battles, campaigns, sieges, political negotiations, and treaties give ample opportunities for the deployment of a phrase which functions as a discourse marker, signalling how these events are to be understood by listeners. It also serves the demands of metrics. In almost all cases, vrô and its negative equivalent appear at the end of a line, and as in the previous example, invariably rhyme with a handful of adverbs: $d \hat{o}$ ('then'), so ('so, thus') and alsô ('thus, therefore'). These three words have fairly general meanings and thus are clearly only used to facilitate the deployment of the vrôfunvrô construction. 


\section{AudienCE AND Performance}

The foregoing discussion has shown how, although the Livonian Rhymed Chronicle was composed in writing and performed by being read aloud from the written text, it contains numerous examples of formulas known from the earlier, orally transmitted poetry. Three main types are evident: fixed nominal collocations filling a complete line; introductory formulas employed to focus on a place or personage which will play a major role in subsequent narrative; and discourse markers which provide positive or negative summations on complete descriptions of events. It thus shows far greater similarity with older works like the Nibelungenlied than with the newer Arthurian romances such as Wolfram's Parzival. This raises the question why the Rhymed Chronicle was more conservative and less innovative than many other poetic works which were in circulation by the time it was written.

Studies of oral-formulaic poetry have emphasised the constraints of memory as a major factor in performance (Lord 65; Kuiper). Such factors obviously did not apply where the performer had a written text available, but we must also consider additional constraints deriving from the audience and its ability to comprehend the text recited to it. Earlier scholarship assumed that as the main subject of the Rhymed Chronicle was the history of the Teutonic Order in Livonia, it served as mealtime reading (German: Tischlesung) for the Order's knight brethren, who were largely illiterate men drawn from the lower nobility and knighthood (Helm and Ziesemer 28-29; Kahl; Angermann 11; Fenske and Militzer). However, a significant objection to the Tiscblesung theory is that the Rule of the Order specified that the mealtime reading should consist of the 'word of God' (Gotes wort):

Daruber sal man daz bebalten in allen bûseren, dâ convent von brûderen ist, daz sint zwelf brûdere unde ein commendûr zu der gezal der iungeren unseres herren Thêsu Christi, daz man dâ pflegelîche dî̀ lectien zu tische babe, die alle, die dâ ezzent, mit swîgene sulen hôren, daz in alleine die gûmen ibt werden gespîset, sunder ouch ir ôren bungere nâch Gotes worte. (Perlbach 41)
Moreover, in all houses where there is a convent of brethren, that is twelve brethren and a commander of the number of the disciples of our Lord Jesus Christ, the observance shall be that during the mealtime readings all those who are eating shall listen in silence, so that not only their stomachs should be fed, since their ears also hunger for the word of God. 
The content of the Rhymed Chronicle could not be regarded as the word of God. The Order commissioned Bible translations and paraphrases, as well as saints' lives and homiletic literature, and the direct evidence indicates that it was works such as these that were read aloud at mealtimes (Gärtner; Necke; Mentzel-Reuters; Mohr). By contrast, I have previously argued that the chronicle was in fact primarily aimed at the secular crusaders who came to Livonia to fight alongside the Sword Brethren and the Teutonic Order, appealing to the need for their continued support by highlighting the heroic virtue of the Order's own knights (Murray). Certainly the style of the chronicle is far more martial and heroic in character than the Order's purely religious literature. A problem in associating the chronicle with either group, however, is that it was composed in Middle High German, the language of central and southern Germany. Almost all the knights of both the Sword Brethren and the Teutonic Order who came to Livonia originated from Northern Germany, as did the majority of secular crusaders who campaigned there (Benninghoven 420-68; Fenske and Militzer). The speech of these two groups was certainly Middle Low German (MLG), the range of northern dialects which were distinguished from southern varieties by numerous features, above all consonants which had not undergone the Second Sound Shift. The two tongues were not necessarily mutually comprehensible, and most of those who heard the Rbymed Chronicle being recited were in effect listening to a foreign language, even if it was read aloud by someone from the Low German dialect area. However, Low German was not yet established as a medium for history writing, in contrast to High German, which had been the accepted literary standard throughout the German-speaking lands for over a century. We cannot establish with certainty whether the author's native language was High or Low German, but it is evident that he had little option but to write his chronicle in the prestige variety. ${ }^{10}$ Yet in doing so he was constrained by his audience, most of whom were not necessarily conversant with the literary standard. This meant that the author had to avoid too great subtlety or linguistic complexity, but also made extensive use of formulaic language and discourse markers to reinforce his meaning.

10. There are a few occurrences of MLG forms with unshifted consonants, e.g. kop 'head' (LRC 675) and bliven 'remain, stay' (LRC 1522, 1742, 1894), alongside the standard MHG forms kopf and bliben. These might be an indication that the author was a native speaker of Low German, although in that case we might expect a greater frequency of MLG forms. We should note that MLG bliven occurs only in rhymes with the ethnic name Liven ('Livs'), so most of the few MLG occurrences can be explained by the demands of metrics. 


\section{CONCLUSIONS}

The Livonian Rhymed Chronicle can be considered as a transitional text in its relationship to the two main dynamics of composition and performance in Middle High German literature. While it originated long after written composition was the norm, its language shows numerous features that associate it with the older forms of heroic and epic poetry. The use of introductory formulaic phrases served to highlight names of important people or places and gave listeners a greater chance of recognising them at later points in the narrative, while conventionalised discourse markers were employed to convey positive or negative judgements on actions described. The author of the Livonian Rhymed Chronicle may have lacked the imagination and stylistic ability of poets such as Hartmann von Aue and Wolfram von Eschenbach, but by employing a consciously conservative style and formulaic devices similar to those known from orally composed and transmitted poetry he was able to facilitate the understanding of a key monument of the history of the Teutonic Order.

\section{REFERENCES}

\section{Primary Sources: Editions and Translations}

Bisinieks, Valdis, trans. Livländische Reimchronik / Atskaņu bronika. Riga: Zinātne, 1998.

Bugiani, Piero, trans. Cronaca rimata della Livonia. Viterbo: Vocifuoriscena, 2016. Edwards, Cyril, trans. Wolfram von Eschenbach, Parzival and Titurel. Oxford: Oxford UP, 2006.

Eelmäe, Urmas, trans. Liivimaa vanem riimkroonika. Tallinn: Kirjastus Argo, 2003.

Erec $=$ Erec von Hartmann von Aue. Ed. Albert Lietzmann. Halle an der Saale:

Niemeyer, 1939.

LRC $=$ Livländische Reimchronik. Ed. Leo Meyer. Paderborn: Schöningh, 1876.

$\mathrm{NL}=$ Das Nibelungenlied. $20^{\text {th }}$ ed. Ed. Helmut de Boor. Wiesbaden: Brockhaus, 1972.

Parzival $=$ Wolfram von Eschenbach, Parzival: Studienausgabe. $6^{\text {th }}$ ed. Ed. Karl Lachmann. Berlin: Walter de Gruyter, 1965.

Perlbach, Max, ed. Die Statuten des Deutschen Ordens nach den ältesten Handschriften. Halle an der Saale: Niemeyer, 1890.

Smith, Jerry C., and William L. Urban, trans. The Livonian Rhymed Chronicle, 2nd ed. Chicago: Lithuanian Research and Studies Center, 2001. 
Secondary Sources

Angermann, Norbert. "Die mittelalterliche Chronistik". Geschichte der deutschbaltischen Geschichtsschreibung. Ed. Georg von Rauch. Köln: Böhlau, 1986. 3-20.

Bäuml, Franz H. "The Oral Tradition and Middle High German Literature". Oral Tradition 1 (1986): 398-445.

Bäuml, Franz H., and Donald J. Ward. "Zur mündlichen Überlieferung des Nibelungenliedes". Deutsche Vierteljahrsschrift für Literaturwissenschaft und Geistesgeschichte 41 (1967): 351-90.

Benninghoven, Friedrich. Der Orden der Scbwertbrïder: Fratres Milicie Cbristi de Livonia. Köln: Böhlau, 1965.

Bihrer, Andreas. "Mäzene und Mäzenatentum im Mittelalter. Perspektiven für die Geschichtswissenschaft". Mäzenaten im Mittelalter aus europäischer Perspektive: Von historischen Akteuren bis zu literarischen Textkonzepten. Eds. Bernd Bastert, Timo Reuvekamp-Felber and Andreas Bihrer. Göttingen: V\&R unipress, 2017. 25-52.

Brüggen, Elke, and Dorothee Lindemann. "Unschärfen. Überlegungen zur Syntax des Parzival”. PerspektivWechsel oder: Die Wiederentdeckung der Philologie, 2: Grenzgänge und Grenzüberschreitungen. Zusammenspiele von Sprache und Literatur in Mittelalter und Früher Neuzeit. Eds. Nina Bartsch and Simone Schultz-Balluff. Berlin: Erich Schmidt, 2016. 397-432.

Bumke, Joachim. The Concept of Knighthood in the Middle Ages. New York: AMS Press, 1982.

Bumke, Joachim. Mäzene im Mittelalter: Die Gönner und Auftraggeber der böfischen Literatur in Deutschland, 1150-1300. München: Beck, 1979.

Capek, Michael J. "A Note on Oral Formulism in the Nibelungenlied". Modern Language Notes 80 (1965): 487-89.

Curschmann, Michael. "Oral Poetry in Mediaeval English, French, and German Literature: Some Notes on Recent Research”. Speculum 42 (1967): 36-52.

Curschmann, Michael. "Nibelungenlied und Nibelungenklage: Über Mündlichkeit und Schriftlichkeit im Prozeß der Episierung”. Deutsche Literatur im Mittelalter - Kontakt und Perspektiven: Hugo Kubn zum Gedenken. Ed. Christoph Cormeau. Stuttgart: Metzler, 1979. 85-119.

Fenske, Lutz, and Klaus Militzer. Ritterbrüder im livländischen Zweig des Deutschen Ordens. Köln: Böhlau, 1993.

Gärtner, Kurt. "Marienverehrung und Marienepik im Deutschen Orden". Mittelalterliche Kultur und Literatur im Deutschordenstaat in Preussen: Leben 
und Nacbleben. Eds. Jarosław Wenta, Sieglinde Hartmann and Gisela Vollmann-Profe. Torun: Wydawnictwo Naukowe Uniwersytetu Mikołaja Kopernika, 2008. 395-410.

Hahn, Reinhard. Geschichte der mittelalterlichen deutschen Literatur Thüringens. Köln: Böhlau, 2012.

Hartmann, Heiko. Einführung in das Werk Wolframs von Eschenbach. Darmstadt:

Wissenschaftliche Buchgesellschaft, 2015.

Haymes, Edward R. "The Germanic Heldenlied and the Poetic Edda: Speculations on Preliterary History". Oral Tradition 19 (2004): 43-62.

Haymes, Edward R. Mündliches Epos in mittelhochdeutscher Zeit. Göppingen: Kümmerle, 1975.

Haymes, Edward R. "Oral Poetry and the Germanic Heldenlied". Rice University Studies 62 (1976): 47-54.

Heinzle, Joachim. "Zum literarischen Status des Nibelungenliedes". Nibelungenlied und Klage: Ursprung - Funktion - Bedeutung. Symposium Kloster Andechs 1995 mit Nachträgen bis 1998. Eds. Dietz-Rüdiger Moser and Marianne Sammer. München: Institut für Bayerische Literaturgeschichte der Ludwig-Maximilian-Universität München, 1998. 49-65.

Helm, Karl, and Walter Ziesemer. Die Literatur des Deutschen Ritterordens. Gießen: Wilhelm Schmitz, 1951.

Jackson, William Henry. Chivalry in Twelfth-Century Germany: The Works of Hartmann von Aue. Cambridge: D. S. Brewer, 1994.

Kahl, Hans-Dietrich. "Zur kulturellen Stellung der Deutschordensritter in Preußen". Die Rolle der Ritterorden in der mittelalterlichen Kultur. Ed. Zenon Hubert Nowak. Torun: Wydawnictwo Naukowe Uniwersytetu Mikołaja Kopernika, 1985. 37-64.

Kala, Tiina. "The Incorporation of the Northern Baltic Lands into the Western Christian World". Crusade and Conversion on the Baltic Frontier, 11501500. Ed. Alan V. Murray. Aldershot: Ashgate, 2001. 3-20.

Kugler, Hartmut. "Über die Livländische Reimchronik: Text, Gedächtnis und Topographie”. Fabrbuch der Brïder Grimm-Gesellschaft 2 (1992): 95-104. Kuiper, Koenraad. "On the Linguistic Properties of Formulaic Speech". Oral Tradition 15 (2000): 279-305.

Lord, Albert B. The Singer of Tales. Cambridge, MA: Harvard UP, 1960. Mentzel-Reuters, Arno. "Deutschordensliteratur' im literarischen Kontext”. Mittelalterliche Kultur und Literatur im Deutschordenstaat in Preussen: Leben und Nacbleben. Eds. Jarosław Wenta, Sieglinde Hartmann and Gisela 
Vollmann-Profe. Toruń: Wydawnictwo Naukowe Uniwersytetu Mikołaja Kopernika, 2008. 355-68.

Meyer, Leo. "Zur Livländischen Reimchronik”. Zeitschrift für deutsche Philologie 4 (1873): 407-24.

Mitchell, Stephen A. "Courts, Consorts, and the Transformation of Medieval Scandinavian Literature”. NOWELE 31-32 (1998): 229-41.

Mohr, Robert. "Die Tischlesung im Deutschen Orden. Eine institutionsspezifische Lehrform". Das Mittelalter: Perspektiven mediävistischer Forschung 17 (2012): 76-86.

Murray, Alan V. "The Structure, Genre and Intended Audience of the Livonian Rhymed Chronicle". Crusade and Conversion on the Baltic Frontier, 1150-1500. Ed. Alan V. Murray. Aldershot: Ashgate, 2001. 235-51.

Necke, Michael. "Strategien der Identitätsstiftung. Zur Rolle der Bibelepik im Deutschen Orden (13./14. Jahrhundert)". Mittelalterliche Kultur und Literatur im Deutschordenstaat in Preussen: Leben und Nachleben. Eds. Jarosław Wenta, Sieglinde Hartmann and Gisela Vollmann-Profe. Toruń: Wydawnictwo Naukowe Uniwersytetu Mikołaja Kopernika, 2008. 461-72.

Ridder, Klaus. "Autorbilder und Werkbewußtsein im Parzival Wolframs von Eschenbach". Wolfram Studien, Xv: Neue Wege der Mittelalter-Pbilologie. Landshuter Kolloquium 1996. Eds. Joachim Heinzle, L. Peter Johnson and Gisela Vollmann-Profe. Berlin: Erich Schmidt Verlag, 1998. 168-94.

Tarvel, Enn. "Livländische Chroniken des 13. Jahrhunderts als Quelle für die Geschichte des Schwertbrüderordens und Livlands". Werkstatt des Historikers der mittelalterlichen Ritterorden: Quellenkundliche Problemund Forschungsmethoden. Toruń: Uniwersytet Mikołaja Kopernika, 1987. 175-84. 